\title{
Investigation on operating parameters and cost using an electrocoagulation process for wastewater treatment
}

\author{
Million Ebba ${ }^{1}$ Perumal Asaithambi ${ }^{1}$ (1) Esayas Alemayehu ${ }^{1,2}$
}

Received: 30 November 2020 / Accepted: 18 October 2021 / Published online: 23 October 2021

(c) The Author(s) 2021

\begin{abstract}
Wastewater generated from different sources affects the health of living organisms and the natural environment due to the availability of different pollutants. Electrocoagulation (EC) is a good technology implemented for wastewater treatment before discharging to an environment as effluents. The electrocoagulation process is an effective method to the remove the color, chemical oxygen demand (COD), turbidity, and consumption of less energy from wastewater by considering different operating parameters. In this study, the major operating parameters for the electrocoagulation process such as $\mathrm{pH}(3-7.50)$, electric current (0.03-0.09 A), electrolytic concentration (1-3 g/L), the distance between electrodes $(1-2 \mathrm{~cm})$, electrolysis time (20-60 min) and combination of electrodes ( $\mathrm{Fe}-\mathrm{Fe}$ and $\mathrm{Al}-\mathrm{Al})$ were studied. The maximum removal of color-94.40\%, COD-97.02\%, and turbidity-90.91\% with required energy consumption $-36 \mathrm{kWhr} / \mathrm{m}^{3}$ was obtained at the electric current-0.09 A, electrolyte concentration $-3 \mathrm{~g} / \mathrm{L}, \mathrm{pH}-7$, electrode combination-Fe-Fe, and distance between electrodes $-3 \mathrm{~cm}$, respectively. The studied parameters were affected the removal \% color, \% COD, \% turbidity, and also the consumption of energy depending on the desired setup of fixed values of the parameter. Consumption of energy and electrode dissolution is related to the cost of operating in electrocoagulation in addition to the cost of labor and the small amount of sludge produced for disposal.
\end{abstract}

Keywords Electrocoagulation $\cdot$ Operating cost $\cdot$ Operating parameters $\cdot$ Wastewater $\cdot$ Removal efficiency $\cdot$ Energy

\section{Introduction}

Water is a fundamental requirement for all living organisms but proper, and clean water supply for different purposes is the biggest problem in the world especially in developing countries due to the lack of economic resources implemented for the water project scheme (Muhammad et al. 2015; Moussa et al. 2016; Benalia et al. 2018; Latheef et al. 2019). Even if there is not enough water supply for a variety of activities, there is always a probability of wastewater

Perumal Asaithambi

asaithambi.perumal@ju.edu.et;

drasaithambi2014@gmail.com

1 Department of Water Supply and Environmental Engineering, Faculty of Civil and Environmental Engineering, Jimma Institute of Technology, Jimma University, Po Box - 378, Jimma, Ethiopia

2 Africa Center of Excellence for Water Management, Addis Ababa University, Po Box-1176, Addis Ababa, Ethiopia being discharged based on the amount of water consumed (Muhammad et al. 2015).

Several sources of wastewater emit the pollutants to the environments such as pulp and paper industries (Mahesh et al. 2016; Kumar and Sharma 2019), garage service giving area (Manilal et al. 2017), printing (Safwat 2020), mining (Touahria et al. 2016), tannery (Deghles 2019), oil refining (Ugya et al. 2018), slaughterhouses (Yusoff et al. 2017), brewery (Papadopoulos et al. 2020), textile (Dalvand et al. 2011), municipal (Gholami Yengejeh et al. 2017), domestic (Ozyonar and Karagozoglu 2011), and hospital (Sharma and Mane 2017).

Among this hospital is a large institution that needs a huge quantity of water to perform daily activities which enhance large volumes of wastewater discharging from chemical and biological laboratories, surgery, drug treatments, radiology, operation room, toilet, and laundry rooms (Sharma and Mane 2017). Direct generation of wastewater from the concerned sources has its impacts such as minimizing the quantity of freshwater and causing environmental pollution especially irreversible problems and generally 
affects flora and fauna (Manilal et al. 2017; Sharma and Mane 2017). The treatment of wastewater generated from different sources is essential for the safety of an environment that is either directly or indirectly related to an environment (Brahmi and Bouguerra 2015). But to eradicate those problems, there are different types of wastewater treatment methods which include a physical, biological, and chemical process based on the different situations of wastewater (Dalvand et al. 2011; Asaithambi 2016; Manilal et al. 2017; Zailani and Zin 2018; Kumar and Sharma 2019).

According to (Moussa et al. 2017), physical treatment is a process that concerns the physical removal of unwanted substances from wastewater without causing any change of biological and physical characteristics of water treated, while the chemical process is the addition of chemicals that react with the pollutants to remove them and the biological unit is done through application or utilization of microorganisms for the biodegradation of pollutants from wastewater. The treatment methods are implemented for the wastewater treatment such as adsorption (Mahesh et al. 2016; Liu et al. 2017; Kamar et al. 2018), coagulation-flocculation (Liu et al. 2017; Manilal et al. 2017), filtration (Liu et al. 2017), ion exchange (Kamar et al. 2018), chemical oxidation (Mahesh et al. 2016; Sharma and Mane 2017), electrocoagulation (Mahesh et al. 2016; Sharma and Mane 2017; Safwat 2020), electrodialysis (Kamar et al. 2018), aerobic and anaerobic (Mahesh et al. 2016), etc.

Electrocoagulation (EC) is important in water and wastewater treatment technology that combines electrochemical, chemical, and physical mechanisms which are based on electrochemically dissolving cationic metallic species in situ by oxidizing a sacrificial anode only with the applying of electric current (Papadopoulos et al. 2020). The dissolved electrodes form a coagulant species that destabilize and trap pollutants in water and wastewater in the form of suspended particles causing them to form flocs and precipitate, which results in removing pollutants (Papadopoulos et al. 2020). Electrocoagulation process is highly adopted due to the installation and maintenance system being simple, operation cost is low, and production of sludge is a small amount and its ability to combine with other treatment process such as ultrasonic, microwave, and ozone (Sharma and Mane 2017; Hashim et al. 2020, 2021; Abdulhadi et al. 2021; Das et al. 2021).

Different studies are indicated that the electrocoagulation is an effective and efficient process to remove the pollutants for the wastewater, and it is generated from different sources such as brewery industry (Papadopoulos et al. 2020), automobile garage (Manilal et al. 2017), hospital (Sharma and Mane 2017), domestic (Ozyonar and Karagozoglu 2011), pulp and paper (Asaithambi 2016; Mahesh et al. 2016), and mining (Touahria et al. 2016). In addition to this, some researchers describe factors affecting operating parameters using electrocoagulation for wastewater treatment (Asaithambi 2016) and but they are small in number that deals with the operating cost of electrocoagulation (Ozyonar and Karagozoglu 2011). There are only few studies on the removal of color, COD, turbidity with determination of energy consumption from wastewater using electrocoagulation process, and also the comparisons of different types of wastewater for the removal of pollutants by using electrocoagulation process are given in Table. 1.

In this study, the effects of different operating parameter in electrocoagulation processes such as electrolysis time, $\mathrm{pH}$, electric current applied, the distance between electrodes, the combination of electrodes and electrolytic concentration on the removal of $\%$ color, $\%$ COD, $\%$ turbidity, and determination of energy consumption were inverstigated for treatment of wastewater. In addition to this, an operating cost of electrocoagulation was clearly described due to electrode dissolution and energy consumption.

\section{Materials and methods}

\section{Materials}

Wastewater was collected from Jimma University Hospital, Jimma Zone, Oromia regional state, Ethiopia. For wastewater sampling, the grab sampling method was used for wastewater collection and the wastewater was stored in a cold room $\left(+4{ }^{\circ} \mathrm{C}\right)$ to protect against any decay in wastewater quality. The characterization of wastewater was accomplished according to standard methods, and the results are given in Table 2. Different types of materials used during the investigation were: a power source (DC power), aluminum $(\mathrm{Al})$ and iron $(\mathrm{Fe})$ electrodes, electrochemical cell, $\mathrm{COD}$ digester, magnetic stirrer, copper wires, electrical clips, $\mathrm{pH}$ meter, turbidity meter, and UV/Vis spectrophotometer.

\section{Methods}

An experimental setup of electrocoagulation is shown in Fig. 1 with an electrochemical cell volume of $1000 \mathrm{~mL}$. In this process, aluminum $(\mathrm{Al})$ and iron $(\mathrm{Fe})$ electrodes were used as anode and cathode with the dimensions of $6 \mathrm{~cm} \mathrm{x}$ $13 \mathrm{~cm} \times 0.1 \mathrm{~cm}$ (width, length, and thickness), and the effective electrode surface area was $6 \mathrm{~cm} \times 10 \mathrm{~cm} \times 0.1 \mathrm{~cm}$. The inter-electrode distance was varied from 1 to $2 \mathrm{~cm}$. Electrical wires (copper wires) were connected to anode and cathode of direct current (DC) power source to one end and $\mathrm{Al}$ and Fe electrodes on other end after dipping into an electrocoagulation cell with the required depth, respectively. The power is supplied according to the desired current just by varying different factors. An electrode was washed and cleared after certain runs of experiments, and also, since there 
Table. 1 Comparisons of removal efficiencies of different types of wastewater by using electrocoagulation technology

\begin{tabular}{|c|c|c|c|}
\hline Types of wastewater & Removal efficiency & Optimum conditions & Literature \\
\hline $\begin{array}{l}\text { Automotive service } \\
\text { station }\end{array}$ & $\begin{array}{l}\text { Linear alkylbenzene sulfonate (LAS)- } \\
\text { 98.2\%, phenol- } 88.85 \%\end{array}$ & $\begin{array}{l}\mathrm{pH} \text { solution- } 7.5 \text {, current intensity-1.72 A, } \\
\text { reaction time-90 min }\end{array}$ & (Emamjomeh et al. 2020) \\
\hline Landfill leachate & $\begin{array}{l}\text { Color- } 74.57 \% \text {, TOC- } 51.75 \% \text {, power } \\
\text { consumption-14.80 kWh } / \mathrm{m}^{3}\end{array}$ & $\begin{array}{l}\text { Current density- } 5.25 \mathrm{~A} / \mathrm{dm}^{2} \text {, inter-elec- } \\
\text { trode distance }-1 \mathrm{~cm} \text {, and initial effluent } \\
\mathrm{pH}-7.83\end{array}$ & (Asaithambi et al. 2018) \\
\hline $\begin{array}{l}\text { Sugar } \\
\text { industry }\end{array}$ & COD- $82 \%$, color- $84 \%$ & $\begin{array}{l}\text { Current density- } 156 \mathrm{~A}^{-2}, \mathrm{pH}-6 \text {, treatment } \\
\text { time- }-120 \mathrm{~min}\end{array}$ & (Sahu 2019) \\
\hline Industrial wastewater & Color-95\%, turbidity-99.5\%, COD - 85\% & $\begin{array}{l}\text { Current density }-1.43 \mathrm{~mA} / \mathrm{cm}^{2} \text {, the dura- } \\
\text { tion }-20 \mathrm{~min} \text {, and the primary } \mathrm{pH}-6\end{array}$ & (Samir Naje et al. 2021) \\
\hline Real textile wastewater & $\begin{array}{l}\text { TOC-42.5\%, COD-18.6\%, turbid- } \\
\text { ity-83.5\%, TSS-64.7\%, color-90.3- } \\
94.9 \%\end{array}$ & $\begin{array}{l}\text { Electrode-Al, current density-25 mA/ } \mathrm{cm}^{2} \text {, } \\
\text { pH-5 }\end{array}$ & (Bener et al. 2019) \\
\hline Livestock wastewater & Color-95.2\%, COD - $93 \%$ & $\begin{array}{l}\mathrm{pH}-8 \text {, current density }-30 \mathrm{~mA} / \mathrm{cm}^{2} \text {, elec- } \\
\text { trolysis time- }-30 \text { min and } \mathrm{NaCl} \text { concen- } \\
\text { tration }-1 \mathrm{~g} / \mathrm{L} \text {, }\end{array}$ & (Tak et al. 2015) \\
\hline Pulp and paper industry & $\begin{array}{l}\text { COD- } 85 \% \text {, power consumption-5.16 } \\
\mathrm{kWh} / \mathrm{m}^{3}\end{array}$ & $\begin{array}{l}\text { COD-2,500 ppm, current density- } 0.40 \\
\mathrm{~A} / \mathrm{dm}^{2}, \mathrm{pH}-7.0 \text {, inter-electrode dis- } \\
\text { tance- } 1 \mathrm{~cm} \text {, reaction time }-120 \mathrm{~min}\end{array}$ & (Asaithambi 2016) \\
\hline Distillery industrial effluent & $\begin{array}{l}\text { Color-90.57\%, COD }-86.54 \% \text {, electrical } \\
\text { energy consumption }-3.50 \mathrm{kWhr} / \mathrm{m}^{3}\end{array}$ & $\begin{array}{l}\mathrm{COD}-3000 \mathrm{mg} / \mathrm{L} \text {, wastewater } \mathrm{pH}-7 \text {, cur- } \\
\text { rent density- } 0.4 \mathrm{~A} / \mathrm{dm}^{2} \text {, inter-electrode } \\
\text { spacing }-1 \mathrm{~cm} \text {, treatment time }-3.5 \mathrm{~h}\end{array}$ & (Asaithambi et al. 2021) \\
\hline Wastewater & $\begin{array}{l}\text { Color-94.44\%, Turbidity-90.91\%, COD } \\
-97.02 \%,\end{array}$ & $\begin{array}{l}\mathrm{pH}-7.5 \text {, electric current- } 0.09 \mathrm{~A} \text {, electro- } \\
\text { lytic concentration }-3 \mathrm{~g} / \mathrm{L} \text {, the distance } \\
\text { between electrodes }-2 \mathrm{~cm} \text {, electrolysis } \\
\text { time- } 60 \text { min, combination of electrodes- } \\
\mathrm{Fe}-\mathrm{Fe}\end{array}$ & This study \\
\hline
\end{tabular}

Table. 2 Characteristics of wastewater

\begin{tabular}{llll}
\hline No & Parameters & Quantity & Unit \\
\hline 1 & $\mathrm{pH}$ & 7.8 & - \\
2 & Color (Absorbance) & 2.95 & - \\
3 & Turbidity & 375 & $\mathrm{NTU}$ \\
4 & COD & 448 & $\mathrm{mg} / \mathrm{L}$ \\
5 & Total Suspended Solids (TSS) & 121 & $\mathrm{mg} / \mathrm{L}$ \\
6 & Total Dissolved Solids (TDS) & 512 & $\mathrm{mg} / \mathrm{L}$ \\
7 & Total Solids (TS) & 633 & $\mathrm{mg} / \mathrm{L}$ \\
\hline
\end{tabular}

was electrode dissolution, they were replaced to enhance the efficiency of the study. The removal degree of color, turbidity, COD, and energy consumption was determined under different operating parameters like $\mathrm{pH}$, the distance between electrodes, current, electrolytic concentration, the combination of electrodes, and electrolysis time. During the process with required experimental conditions, the samples were collected at regular intervals of time and centrifuged using REMI Model: R-24 (10,000 rpm, $15 \mathrm{~min}$ ), and were analyzed for color, COD, and turbidity removal. The color was measured at the wavelength corresponding to maximum absorbance $\lambda \max (300 \mathrm{~nm})$ using a UV/Vis spectrophotometer (Jasco, V-570). The COD of the samples was determined

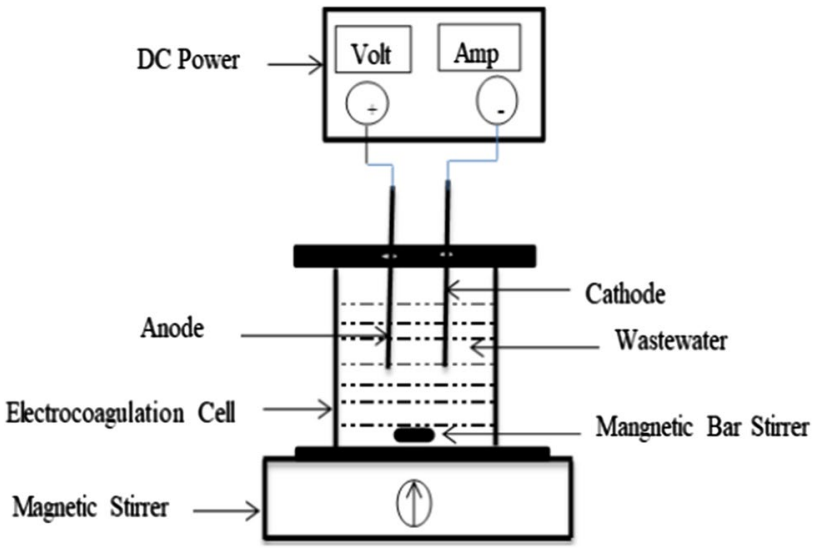

Fig. 1 Electrocoagulation setup

using the dichromatic closed reflux method, strictly following the APHA.

\section{Analysis}

Different wastewater parameters were analyzed based on the factors influencing the investigation of the electrocoagulation process. The removal of color, turbidity, COD, and 
power consumption was studied by using different empirical formulas.

\section{Percentage removal of COD, color, turbidity, and energy consumption}

The removal efficiency of COD, color, turbidity, and power (energy) consumption was determined according to the formulas stated below.

$\operatorname{COD}(\%)=\frac{\mathrm{COD}_{0}-\mathrm{COD}_{\mathrm{t}}}{\mathrm{COD}_{\mathrm{o}}} * 100$

where $\mathrm{COD}_{\mathrm{o}}$ and $\mathrm{COD}_{\mathrm{t}}$ are the chemical oxygen demand $(\mathrm{COD})$ at time $=0$ (initial) and at $\mathrm{t}$ (reaction time, $\mathrm{t}$ ), respectively.

$\operatorname{Color}(\%)=\frac{A_{0}-A_{t}}{A_{0}} * 100$

where $A_{0}$ and $A_{t}$ are absorbance registered at time $\mathrm{t}=0$ (initial) and at $\mathrm{t}$ (reaction time), respectively.

Turbidityremoval $(\%)=\frac{C_{0}-C_{t}}{C_{0}} * 100$

where $C_{0}$ and $C_{t}$ are turbidity registered (in NTU) at time $\mathrm{t}=0$ (initial) and at $\mathrm{t}$ (reaction time), respectively.

Energy $=\frac{\mathrm{VIt}}{\mathrm{V}_{\mathrm{R}}}$

where $\mathrm{V}, \mathrm{I}$, and $\mathrm{t}$ stand for average voltage of the EC system (V), electrical current intensity (I), and reaction time $(t)$, respectively, and $V_{R}$ is the volume of wastewater, respectively.

In the electrocoagulation process, calculating an operating cost is important which consists of material (electrodes and electrical energy) as well as other essential expenses consisting of sludge dewatering and disposal, but low operating costs could be calculated (Brahmi and Bouguerra 2015).

Operating Cost $=a C_{\text {energy }}+b C_{\text {electrode }}+D$

where a is electrical energy price in $\$ / \mathrm{kWhr}$, b is electrode material price in $\$ / \mathrm{kg}$, D is cost of chemicals, and $\mathrm{C}_{\text {energy }}$ and $\mathrm{C}_{\text {electrode }}$ are energy and electrode consumption, respectively.

Here, $\mathrm{C}_{\text {energy }}$ can be determined using Eq. (4).

$C_{\text {electrode }}\left(\mathrm{kg} / \mathrm{m}^{3}\right)=\frac{\mathrm{ItM}}{\mathrm{nFV}}$

where $\mathrm{M}$ is molecular mass of $\mathrm{Al}$ and $\mathrm{Fe}$ (26.98 and $55.85 \mathrm{gmol}^{-1}$ ), respectively, $\mathrm{n}$ is the number of electrons transferred $\mathrm{Al}$ and $\mathrm{Fe}(\mathrm{Z}=3$ and $\mathrm{Z}=2)$, respectively, $\mathrm{F}$ is Faraday's constant $\left(96,487 \mathrm{C} \mathrm{mol}^{-1}\right)$, and $\mathrm{V}$ is a volume $\left(\mathrm{m}^{3}\right)$.

\section{Results and discussion}

\section{Factors affecting electrocoagulation}

Wastewater treatment by using electrocoagulation process can be done by considering different factors. In this study, $\mathrm{pH}$ of wastewater, electrolytic concentration, current, reaction time, electrode type, the distance between electrodes, and way of electrode combined are considered as a factor to treat the wastewater.

\section{pH}

The $\mathrm{pH}$ of the wastewater sample is not the same. It is adjusted by a solution of $\mathrm{NaOH}$ and $\mathrm{H}_{2} \mathrm{SO}_{4}$ and checked by a pH meter (Ozyonar and Karagozoglu 2011). In this study, the $\mathrm{pH}$ of wastewater was adjusted to $\mathrm{pH} 3,6$, and 7.5 for both $\mathrm{A} 1-\mathrm{Al}$ and $\mathrm{Fe}-\mathrm{Fe}$ electrode combinations. Keeping the $\mathrm{pH}$ of the wastewater sample constant, the removal efficiency of color, COD, and turbidity obtained was different by changing other affecting factors. The laboratory results indicate that as $\mathrm{pH}$ increases, the removal efficiency and energy were increased (Fig. 2). This is because the increase in $\mathrm{pH}$ during $\mathrm{EC}$ process was primarily attributed to the evolution of hydrogen gas at the cathode, and the concentration of hydroxyl ions $\left(\mathrm{OH}^{-}\right)$increases in the solution due to the electrochemical reactions that result in high removal efficiency (Taylor and Asaithambi 2015). This happens when all the above-mentioned factors are considered such that the values for color, turbidity, COD removal, and power consumption were obtained. However, most studies show that at a high $\mathrm{pH}$ value the removal efficiency of different impurities obtained is minimum (Mansooreh D. et al. 2014).

\section{Electrolytic concentration}

Electrolytic concentration is one factor that affects the electrocoagulation process. The sodium chloride $(\mathrm{NaCl})$ was used as electrolyte and different concentrations were added to one liter of the sample such that different results were obtained. Concentrations of $\mathrm{NaCl}$ used in these activities are 1,2 , and $3 \mathrm{~g} / \mathrm{L}$ by keeping all other parameters constant. As the concentration of $\mathrm{NaCl}$ added per liter of wastewater sample increases, the removal efficiency also increases (Fig. 3). According to (Asaithambi et al. 2012), this was due to positive addition in $\mathrm{NaCl}$ concentration which enhanced the production of oxidizing agent, thus increasing the conductivity of the solution which resulted in high removal of pollutants. Even if the concentration of $\mathrm{NaCl}$ is varied, the removal efficiency of pollutants is increased with increasing 
(a)

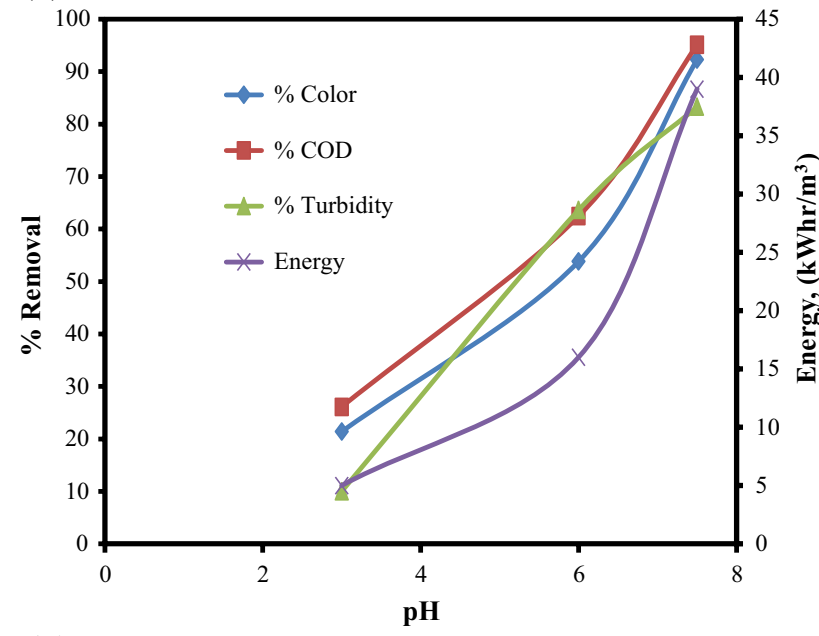

(b)

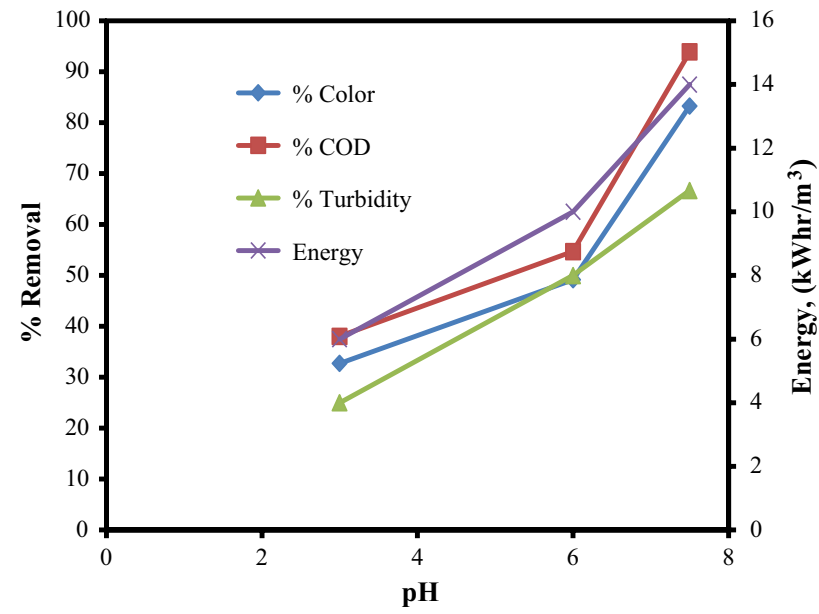

Fig. 2 Removal efficiency and power consumption versus $\mathrm{pH}$ on a $\mathrm{Al}$ and $\mathbf{b} \mathrm{Fe}$

the concentration of $\mathrm{NaCl}$ (Kabda 2008; Sharma and Verma 2017).

\section{Current}

It is the amount of electric current in ampere applied to electrocoagulation process for wastewater treatment taken during electrochemical process. By varying the value of electric current applied to the electrocoagulation process with different parameters, the removal efficiency also varies. Increasing the current in ampere.

increases the removal efficiency of color, COD, turbidity, and consumption of energy (Fig. 4). A higher removal value of pollutants is observed, while a gradual increment of electric current is applied (Kabda 2008; Sharma and Verma 2017). This can be attributed due to the fact that the applied current determines the rates of coagulant and (a)

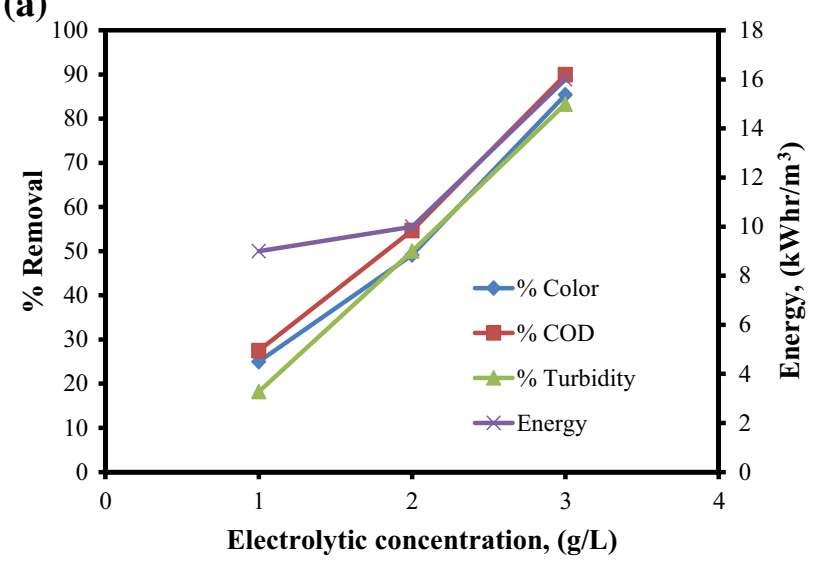

(b)

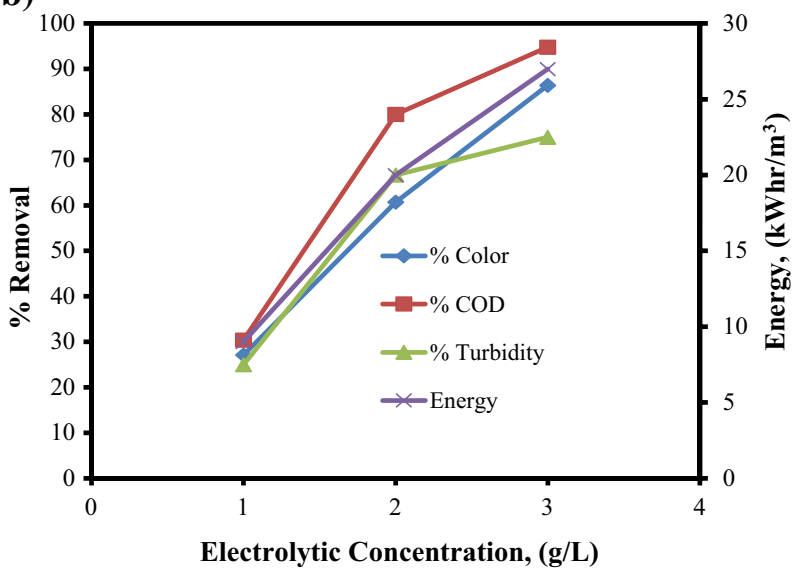

Fig. 3 Removal efficiency and power consumption versus electrolytic concentration on $\mathbf{a} \mathrm{Al}$ and $\mathbf{b} \mathrm{Fe}$

bubble production, which in turn can increase the pollutant removal efficiency.

\section{Reaction time}

Reaction time is the time needed to complete the reaction process of a sample which affects the electrocoagulation process. According to this activity, the reaction time is one hour in which the removal efficiency is checked at a 20 min interval using the initial value as a baseline. In this investigation, the laboratory result shows one hour reaction time is somewhat enough to remove pollutants such that increasing an electrolysis time increases the removal degree of pollutants and consumption of energy (Fig. 5). Increasing the reaction time increases the removal efficiency of color, turbidity, and COD with energy consumption from wastewater (Kabda 2008; Sharma and Verma 2017). According to (Asaithambi et al. 2016), increasing the reaction time resulted in higher removal efficiency due to the generation of hydroxyl radicals and more metal polymeric species were formed. 
(a)

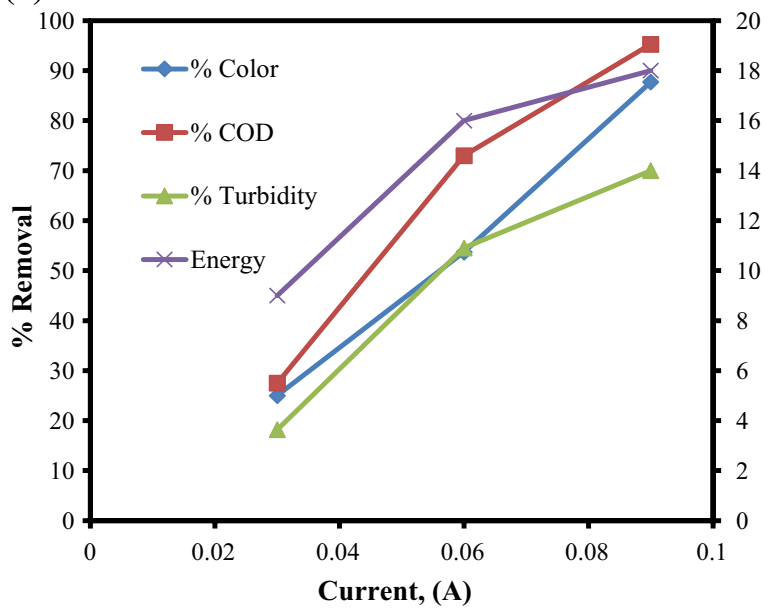

(b)

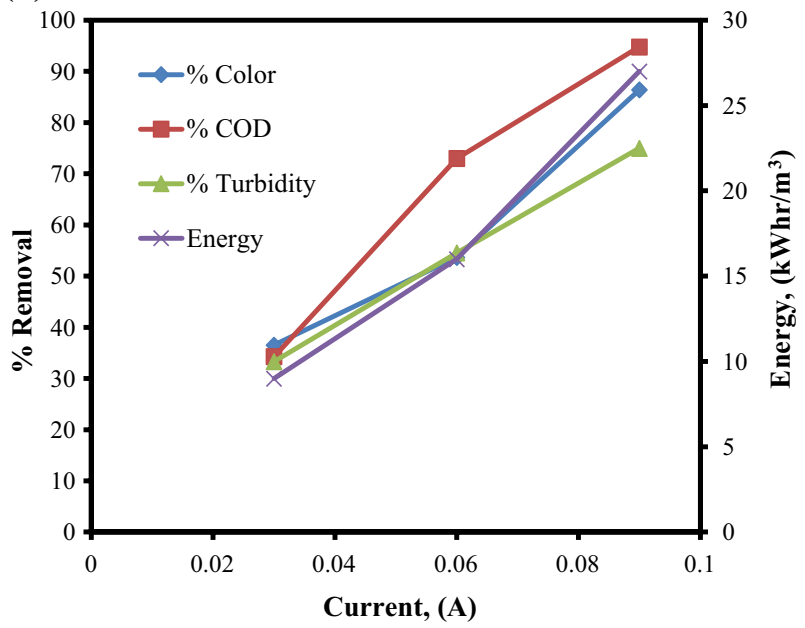

Fig. 4 Removal efficiency and power consumption versus current on a $\mathrm{Al}$ and $\mathbf{b} \mathrm{Fe}$

\section{Distance between electrodes and types of electrodes}

Distance between electrodes is the gap formed between the anode and cathode. In this study, the distance between electrodes taken were $1,1.50$, and $2 \mathrm{~cm}$, respectively. So as the distance between electrodes increases, the removal efficiency also increases energy (Fig. 6). This is because the increase in the inter-electrode distance has a direct relationship with current and resistance which increases the cell voltage (Asaithambi et al. 2012). Types of electrodes are also other factors that affect electrocoagulation and can be selected based on their availability on the market, cost, and effectiveness.

\section{Electrode combination}

The combination of electrodes is also another factor that affects electrocoagulation on the percentage removal of

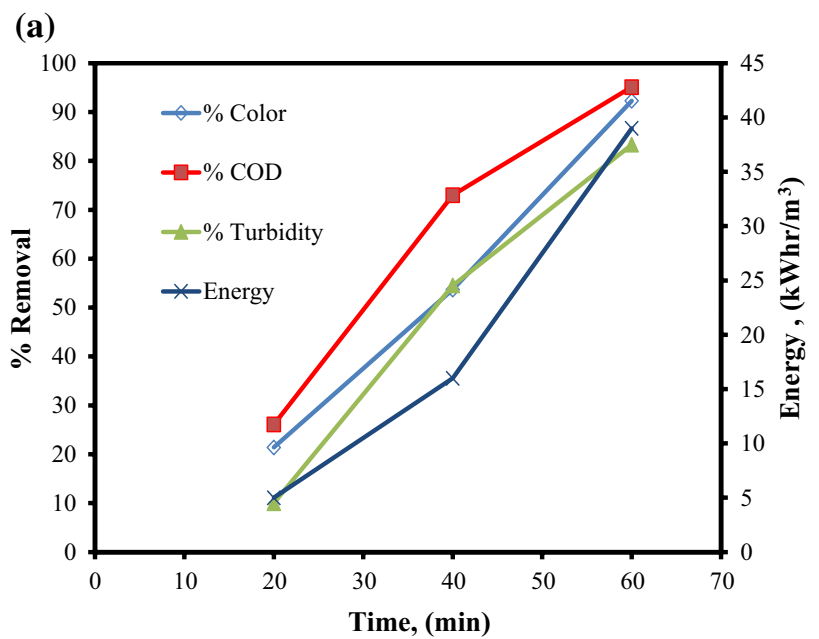

(b)

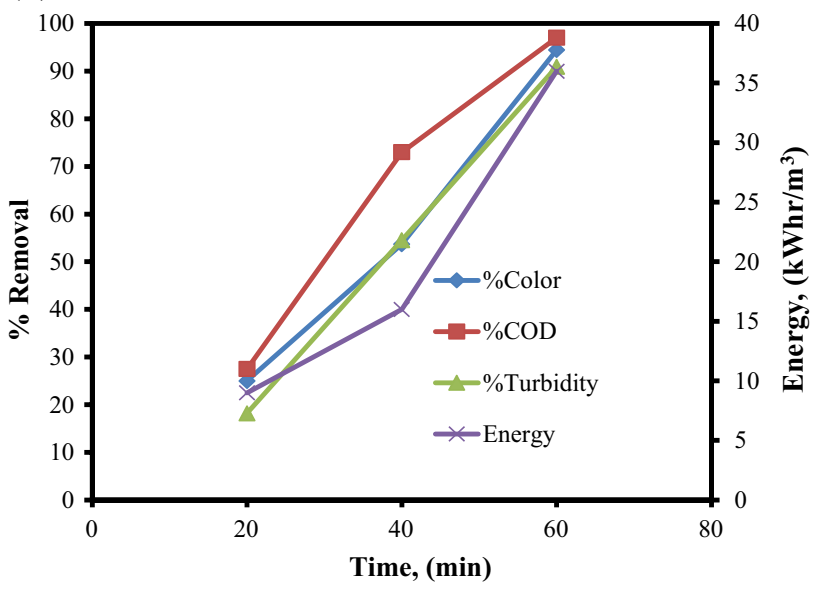

Fig. 5 Removal efficiency and power consumption versus electrolysis time on $\mathbf{a} \mathrm{Al}$ and $\mathbf{b} \mathrm{Fe}$

pollutant from wastewater. In electrocoagulation process, a common type of electrodes used was $\mathrm{Al}, \mathrm{Fe}$, and stainless steel where those electrodes were selected based on their availability on the local market, their cost, and effectiveness. In this study, $\mathrm{Al}-\mathrm{Al}$ and $\mathrm{Fe}-\mathrm{Fe}$ combinations were used to evaluate the above-mentioned operating parameters for the \% color, \%COD and \% turbidity removal along with determination of consumption of energy from wastewater. According to the experimental results, there is a chemical reaction of $\mathrm{Al}$ and $\mathrm{Fe}$ in the electrocoagulation process which forms coagulants of hydroxide flocs that absorb pollutants from wastewater. Experimental investigation indicates using $\mathrm{Fe}-\mathrm{Fe}$ electrode combination to remove more percentage of color, $\mathrm{COD}$, and turbidity and there is less power consumed than using $\mathrm{Al}-\mathrm{Al}$ electrode combination. 
(a)

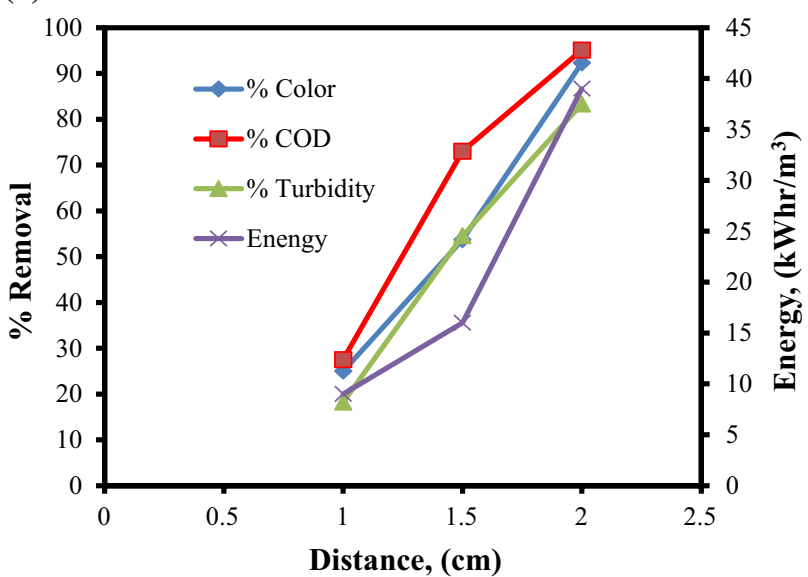

(b)

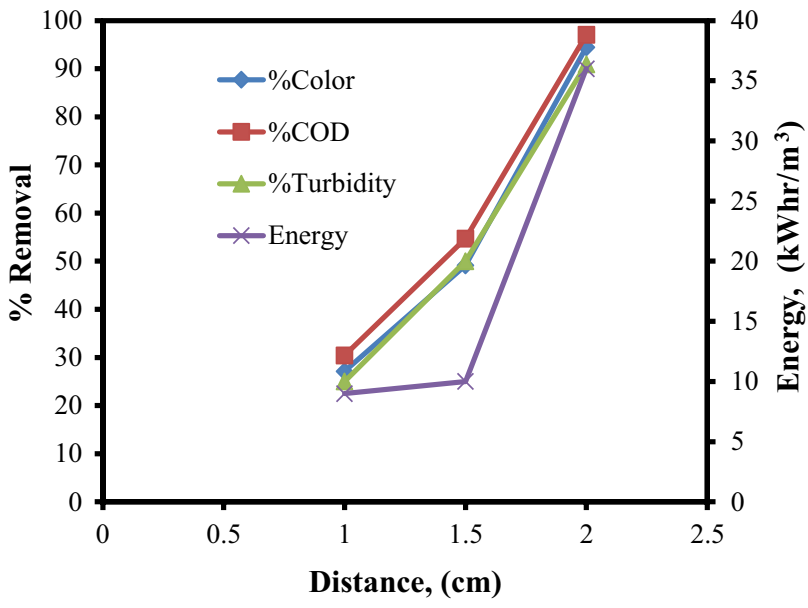

Fig. 6 Removal efficiency and power consumption versus distance between electrodes on $\mathbf{a} \mathrm{Al}$ and $\mathbf{b} \mathrm{Fe}$

\section{Estimation of operating cost for electrocoagulation}

Electrocoagulation process is an essential technology needed in wastewater treatment without adding any chemicals such that determining the whole operating cost of the process is mandatory; however, few studies determine the total operating cost of an electrocoagulation process (Moussa et al. 2016). The operating cost of electrocoagulation is a major disadvantage of the technology especially for practical application of large-scale industry, and also, few papers were done on the assessment of operating cost (Moussa et al. 2016).

The total operating cost of the electrocoagulation process consists of material, electrical energy costs, labor cost, maintenance cost, dewatering of sludge and disposal cost, and fixed costs (Kobya et al. 2016). However, different costs are not included in the calculation part and they are assumed to be fixed, like costs of dewatering of sludge, labor, maintenance, and costs of disposal (Can and Kobya 2006).
Among experimental titration, there is a maximum electrode and power consumption for both electrode combinations. Hence, the maximum electrode consumption for $\mathrm{Al}-\mathrm{Al}$ and $\mathrm{Fe}-\mathrm{Fe}$ combination is $0.00279 \mathrm{~kg} / \mathrm{m}^{3}$ and $0.00868 \mathrm{~kg} / \mathrm{m}^{3}$ and the maximum power consumption for $\mathrm{Al}-\mathrm{Al}$ and $\mathrm{Fe}-\mathrm{Fe}$ combination is $39 \mathrm{kWhr} / \mathrm{m}^{3}$ and $36 \mathrm{kWhr} / \mathrm{m}^{3}$, respectively. When the electrodes are bought from the local market, it is simply sold to the customer with the required dimensions and they do not measure the appropriate weight of those electrodes. Each electrode means $\mathrm{Al}$ and Fe were bought by 20 Ethiopian Birr. This is approximately $0.7107 \$$ for a pair of electrodes. This depends on the currency exchange of the Commercial Bank of Ethiopia that indicates the value of one dollar is 28.1407 Ethiopian Birr. The total mass of a pair of electrodes is $30.70 \mathrm{~g}$ and $45.40 \mathrm{~g}$ for $\mathrm{Al}$ and Fe, respectively. Hence, the price of electrodes per weight is 23.15 $\$ / \mathrm{kg}$ and10.557 \$/kg for $\mathrm{Al}$ and $\mathrm{Fe}$, respectively. Hence, the operating cost of the process can easily be determined using Eq. (5). Similarly, energy and electrode consumptions are determined using Eqs. (4) and (6), respectively. This indicates the value of ' $\mathrm{b}$ ' is $23.15 \$ / \mathrm{kg}$ and $10.557 \$ / \mathrm{kg}$ for $\mathrm{Al}$ and $\mathrm{Fe}$, respectively. Hence, $\mathrm{C}_{\text {electrode }}$ cost for $\mathrm{Al}-\mathrm{Al}$ and $\mathrm{Fe}-\mathrm{Fe}$ combination is $0.065 \$ / \mathrm{m}^{3}$ and $0.0916 \$ / \mathrm{m}^{3}$. According to Ethiopian Electric Power Agency, the amount of tariff paid for electrical energy is $0.056 \$ / \mathrm{kWhr}$ per month (Atalo 2018).

Therefore, the total energy consumption cost was 2.184 $\$ / \mathrm{m}^{3}$ and $2.016 \$ / \mathrm{m}^{3}$ for $\mathrm{Al}-\mathrm{Al}$ and $\mathrm{Fe}-\mathrm{Fe}$ combination, respectively. The total cost expended for different types of the chemical was around $2 \$$ for the preparation of $\mathrm{K}_{2} \mathrm{Cr}_{2} \mathrm{O}_{7}$, $\left(\mathrm{NH}_{4}\right)_{2} \mathrm{Fe}\left(\mathrm{SO}_{4}\right)_{2}\left(\mathrm{H}_{2} \mathrm{O}\right)_{6}$, and $\mathrm{H}_{2} \mathrm{SO}_{4}$ solution. According to (Can and Kobya 2006), approximately the total cost of labor, sludge dewatering, and disposal was $1 \$ / \mathrm{m}^{3}$.

Therefore, the sum of the operating cost was $4.15 \$ / \mathrm{m}^{3}$ and $4.01 \$ / \mathrm{m}^{3}$ for $\mathrm{Al}-\mathrm{Al}$ and $\mathrm{Fe}-\mathrm{Fe}$ combination, respectively. Generally, from the above analysis, the $\mathrm{Al}-\mathrm{Al}$ electrode combination is less consumed, but there is a higher energy consumption compared to the $\mathrm{Fe}-\mathrm{Fe}$ combination. The whole operating cost of the $\mathrm{Al}-\mathrm{Al}$ combination is higher than that of the Fe-Fe combination.

\section{Conclusion}

Based on an experimental investigated, electrocoagulation is an effective method for the removal of pollutant with different influencing factors such as $\mathrm{pH}$, electric current, electrolytic concentration, the distance between electrodes, electrolysis time, and types of electrodes which are high affecting the removal efficiency of color, COD, and turbidity with energy consumption. An increasing value of $\mathrm{pH}(3-7.5)$, electric current (0.03 to $0.09 \mathrm{~A})$, electrolytic concentration (1-3 g/L), the distance between electrodes $(1-2 \mathrm{~cm})$, and

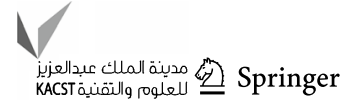


electrolysis time (20-60 min) increases the removal percentage of color, COD, and turbidity. Similarly, the increment of power consumption achieves the highest removal of pollutants from wastewater since it directly depends on those factors. Using a $\mathrm{Fe}-\mathrm{Fe}$ electrode combination can remove more pollutants than using the $\mathrm{Al}$ electrode combination. Operating cost also depends on the cost of power consumption and electrode dissolution, such that an operating cost of Fe electrode is relatively low to $\mathrm{Al}$ electrode.

Funding The authors received no specific funding for this work.

\section{Declarations}

Conflicts of interest The authors declare no conflicts of interest with regard to the publication of this research article.

Ethical approval This article does not contain any studies with human participants or animals performed by any of the authors.

Open Access This article is licensed under a Creative Commons Attribution 4.0 International License, which permits use, sharing, adaptation, distribution and reproduction in any medium or format, as long as you give appropriate credit to the original author(s) and the source, provide a link to the Creative Commons licence, and indicate if changes were made. The images or other third party material in this article are included in the article's Creative Commons licence, unless indicated otherwise in a credit line to the material. If material is not included in the article's Creative Commons licence and your intended use is not permitted by statutory regulation or exceeds the permitted use, you will need to obtain permission directly from the copyright holder. To view a copy of this licence, visit http://creativecommons.org/licenses/by/4.0/.

\section{References}

Abdulhadi B, Kot P, Hashim K et al (2021) Continuous-flow electrocoagulation (EC) process for iron removal from water: Experimental, statistical and economic study. Sci Total Environ 760:143417. https://doi.org/10.1016/j.scitotenv.2020.143417

Arslan-Alaton I, Kabdaslı I, Sahin Y (2008) Effect of Operating Parameters on the Electrocoagulation of Simulated Acid Dyebath Effluent. Open Environ Biol Monitoring J 1:1-7

Asaithambi P (2016) Studies on various operating parameters for the removal of COD from pulp and paper industry using electrocoagulation process. Desalin Water Treat 57:11746-11755. https:// doi.org/10.1080/19443994.2015.1046149

Asaithambi P, Susree M, Saravanathamizhan R, Matheswaran M (2012) Ozone assisted electrocoagulation for the treatment of distillery effluent. Desalination 297:1-7. https://doi.org/10.1016/j. desal.2012.04.011

Asaithambi P, Raman A, Aziz A et al (2016) Chemical Engineering and Processing : Process Intensi fi cation Integrated ozone - electrocoagulation process for the removal of pollutant from industrial ef fl uent. Optimization through response surface Methodol 105:92-102

Asaithambi P, Beyene D, Aziz ARA, Alemayehu E (2018) Removal of pollutants with determination of power consumption from landfill leachate wastewater using an electrocoagulation process: optimization using response surface methodology (RSM). Appl Water Sci. https://doi.org/10.1007/s13201-018-0715-9

Asaithambi P, Govindarajan R, Yesuf MB et al (2021) Investigation of direct and alternating current-electrocoagulation process for the treatment of distillery industrial effluent: Studies on operating parameters. J Environ Chem Eng 9:104811. https://doi.org/10. 1016/j.jece.2020.104811

Atalo T (2018) Ethiopia's Electric tarrif Comparision

Benalia A, Derbal K, Panico A, Pirozzi F (2018) Use of acorn leaves as a natural coagulant in a drinking water treatment plant. Water (switzerland) 11:1-12. https://doi.org/10.3390/w11010057

Bener S, Bulca Ö, Palas B et al (2019) Electrocoagulation process for the treatment of real textile wastewater: Effect of operative conditions on the organic carbon removal and kinetic study. Process Saf Environ Prot 129:47-54. https://doi.org/10.1016/j. psep.2019.06.010

Brahmi K, Bouguerra W (2015) Investigation of electrocoagulation reactor design parameters effect on the removal of cadmium from synthetic and phosphate industrial wastewater. Arab J Chem. https://doi.org/10.1016/j.arabjc.2014.12.012

Can OT, Kobya M (2006) Treatment of the Textile Wastewater by Combined Electrocoagulation Treatment of the textile wastewater by combined electrocoagulation. Chemosphere 62(2):181187. https://doi.org/10.1016/j.chemosphere.2005.05.022

Dalvand A, Gholami M, Joneidi A, Mahmoodi NM (2011) Dye Removal, Energy Consumption and Operating Cost of Electrocoagulation of Textile Wastewater as a Clean Process. Clean - Soil, Air, Water 39:665-672. https://doi.org/10.1002/clen. 201000233

Das PP, Anweshan Mondal P et al (2021) Integrated ozonation assisted electrocoagulation process for the removal of cyanide from steel industry wastewater. Chemosphere 263:128370. https://doi.org/ 10.1016/j.chemosphere.2020.128370

Deghles A (2019) Treatment of Tannery Wastewater by the Application of Electrocoagulation Process Using Iron and Aluminum Electrodes. Green Sustain Chem 09:119-134. https://doi.org/10. 4236/gsc.2019.94009

Emamjomeh MM, Mousazadeh M, Mokhtari N et al (2020) Simultaneous removal of phenol and linear alkylbenzene sulfonate from automotive service station wastewater: Optimization of coupled electrochemical and physical processes. Sep Sci Technol 55:31843194. https://doi.org/10.1080/01496395.2019.1675703

Gholami Yengejeh S, Jafari Mansoorian H, Majidi G et al (2017) Efficiency of electrical coagulation process using aluminum electrodes for municipal wastewater treatment a case study at Karaj wastewater treatment plant. Environ Heal Eng Manag 4:157-162. https://doi.org/10.15171/ehem.2017.22

Hashim KS, Ali SSM, AlRifaie JK et al (2020) Escherichia coli inactivation using a hybrid ultrasonic-electrocoagulation reactor. Chemosphere 247:125868. https://doi.org/10.1016/j.chemosphere. 2020.125868

Hashim KS, Shaw A, AlKhaddar R et al (2021) Water purification from metal ions in the presence of organic matter using electromagnetic radiation-assisted treatment. J Clean Prod 280:124427. https://doi. org/10.1016/j.jclepro.2020.124427

Kamar F, Esgair K, Abod B, Nechifor A (2018) Removal of Hexavalent Chromium Ions From the Simulated Wastewater Using Electrocoagulation Process. 111-118. https://doi.org/10.21698/ simi.2018.fp14

Kobya M, Gengec E, Demirbas E (2016) Chemical Engineering and Processing : Process Intensi fi cation Operating parameters and costs assessments of a real dyehouse wastewater ef fl uent treated by a continuous electrocoagulation process. Chem Eng Process Process Intensif 101:87-100. https://doi.org/10.1016/j.cep.2015. 11.012 
Kumar D, Sharma C (2019) Reduction of chlorophenols and sludge management from paper industry wastewater using electrocoagulation process. Sep Sci Technol. https://doi.org/10.1080/01496 395.2019.1646761

Latheef A, Saheed SM, Basheer AK, Johnson J (2019) Water treatment using natural coagulants. Int Res J Eng Technol 06:509-512

Liu J, Zhu G, Wan P et al (2017) Current applications of electrocoagulation in water treatment: A review. Desalin Water Treat 74:53-70. https://doi.org/10.5004/dwt.2017.20371

Mahesh S, Garg KK, Srivastava VC et al (2016) Continuous electrocoagulation treatment of pulp and paper mill wastewater: Operating cost and sludge study. RSC Adv 6:16223-16233. https://doi.org/ $10.1039 / \mathrm{c} 5 \mathrm{ra} 27486 \mathrm{a}$

Manilal AM, Harinarayanan Nampoothiri MG, Soloman PA (2017) Removal of oil and grease from automobile garage wastewater using electrocoagulation. IOP Conf Ser Mater Sci Eng. https:// doi.org/10.1088/1757-899X/206/1/012082

Mansooreh D et al (2014) Treatment of Hospital Wastewater by Electrocoagulation Using Aluminum and Iron Electrodes. Int J Environ Health Eng. https://doi.org/10.4103/2277-9183.132687

Moussa DT, El-naas MH, Nasser M, Al-marri MJ (2016) A comprehensive review of electrocoagulation for water treatment : Potentials and challenges A comprehensive review of electrocoagulation for water treatment : Potentials and challenges. J Environ Manage. https://doi.org/10.1016/j.jenvman.2016.10.032

Moussa DT, El-Naas MH, Nasser M, Al-Marri MJ (2017) A comprehensive review of electrocoagulation for water treatment: Potentials and challenges. J Environ Manage 186:24-41. https://doi.org/ 10.1016/j.jenvman.2016.10.032

Muhammad IM, Abdulsalam S, Abdulkarim A, Bello AA (2015) Water melon seed as a potential coagulant for water treatment. Glob J Res Eng C Chem Eng 15:17-24

Ozyonar F, Karagozoglu B (2011) Ozyonar, F., Karagozoglu, B., 2011. Operating Cost Analysis and Treatment of Domestic Wastewater by Electrocoagulation Using Aluminum Electrodes 20, 173-179.

Papadopoulos KP, Economou CN, Tekerlekopoulou AG, Vayenas DV (2020) Two-step treatment of brewery wastewater using electrocoagulation and cyanobacteria-based cultivation. J Environ Manage 265:110543. https://doi.org/10.1016/j.jenvman.2020.110543

Safwat SM (2020) Treatment of real printing wastewater using electrocoagulation process with titanium and zinc electrodes. J Water
Process Eng 34:101137. https://doi.org/10.1016/j.jwpe.2020. 101137

Sahu O (2019) Suitability of chemical and electrocoagulation process on sugar industry wastewater treatment. Int J Energy Water Resour 3:117-125. https://doi.org/10.1007/s42108-019-00021-z

Samir Naje A, Faisal Naser G, Sadi Samaka I, Al-Zubaidi HAM (2021) Environmental assessment of kinetics behavior of electrocoagulation process for industrial wastewater treatment. Mater Today Proc. https://doi.org/10.1016/j.matpr.2021.05.691

Sharma A, Mane SJ (2017) Removal of Solids from Hospital Wastewater Using Electrocoagulation 7:13313-13315

Sharma A, Verma S (2017) TREATMENT OF HOSPITAL WASTEWATER USING ELECTROCOAGULATION - A REVIEW. Int J Adv Technol Eng Sci 5:9-12

Tak B, yul, Tak B sik, Kim Y ju, et al (2015) Optimization of color and COD removal from livestock wastewater by electrocoagulation process: Application of Box-Behnken design (BBD). J Ind Eng Chem 28:307-315. https://doi.org/10.1016/j.jiec.2015.03.008

Touahria S, Hazourli S, Touahria K et al (2016) Clarification of industrial mining wastewater using electrocoagulation. Int J Electrochem Sci 11:5710-5723. https://doi.org/10.20964/2016.07.51

Ugya AY, Imam TS, Ajibade FO (2018) Remediation of refinery wastewater using lectrocoagulation process. Bayero J Pure Appl Sci 10:57. https://doi.org/10.4314/bajopas.v10i1.12s

Yusoff MS, Azwan AM, Zamri MFMA, Aziz HA (2017) Removal of colour, turbidity, oil and grease for slaughterhouse wastewater using electrocoagulation method. AIP Conf Proc. https://doi.org/ $10.1063 / 1.5005692$

Zailani LWM, Zin NSM (2018) Application of Electrocoagulation in Various Wastewater and Leachate Treatment-A Review. IOP Conf Ser Earth Environ Sci. https://doi.org/10.1088/1755-1315/140/1/ 012052

Publisher's Note Springer Nature remains neutral with regard to jurisdictional claims in published maps and institutional affiliations 